\title{
Studying behavior of navel orange trees under different irrigation treatments in the north middle nile delta.
}

\author{
Moursi, E.A ${ }^{1}$ and M.M Abo El-Enien ${ }^{2}$ \\ 1. Soils, Water and Environment Research Institute. Agric Res. Center, Giza. Egypt. \\ 2. Horticulture Res. Inst. Citrus Department, Agric.Res. Centre- Egypt.
}

\begin{abstract}
This study was carried out to evaluate the effect of three irrigation treatments (irrigation when 25,50 and $75 \%$ of available soil moisture was depleted) in comparison with farm control treatment (traditional irrigation like to practice by local farmers) in the studied area on some water relations, productivity and fruit quality of Washington Navel orange trees under clay soil conditions during two successive seasons 2013 and 2014 at a private orchard in Desok district, Kafr El-Sheikh Governorate. The results showed that, the highest amount of applied water (7838.4 and $7389.8 \mathrm{~m}^{3} / \mathrm{fed}$.), water consumptive use (113. 8 and $109.1 \mathrm{~m}^{3} / \mathrm{fed}$.) and stored water values in the effective root zone (5591.4 and $\left.5391.7 \mathrm{~m}^{3} / \mathrm{fed}\right)$ were recorded under control treatment compared to the lowest values obtained by irrigation treatment when $75 \%$ of available soil moisture was depleted in both seasons respectively. The highest values of water application efficiency $(82.90 \%)$ and consumptive use efficiency $(65.72 \%)$ were recorded under irrigation treatment $75 \%$ of available soil moisture was depleted compared to the lowest values 72.15 and $61.5 \%$ respectively, obtained by control treatment in both seasons. The highest values of Water productivity $\left(7.51\right.$ and $\left.7.52 \mathrm{~kg} / \mathrm{m}^{3}\right)$ and productivity of irrigation water (4.81 and $4.95 \mathrm{~kg} / \mathrm{m}^{3}$ ) were recorded under irrigation treatment $\mathrm{I}_{3}$ in the first and second growing seasons respectively.The trees were irrigated when 50\% of available soil moisture was depleted gave the highest fruit yield and number of fruits per trees and tended to increase peel firmness, and thickness, SSC, acidity, Vit.C, and juice weight compared with the control. For $\mathrm{N}$ and $\mathrm{K}$ concentrations in leaves, results showed that irrigation treatments showed no significant effect on $\mathrm{N}$ and $\mathrm{k}$ but significant effect on $\mathrm{P}$ concentration.
\end{abstract}

Keywords: Navel orange, Irrigation treatments, Water relations, Tree productivity, Fruit quality

\section{Introduction}

Citrus consider is one of the most important fruit crops in the world, especially, under warm temperate regions. However, it occupied the third position between allover the total fruit crops after grapes and apples. Moreover, citrus is a major fruit crop cultivated in Egypt as its acreage, production and exportation potentialities are concerned. It is the largest horticultural industry, during the last few years, and harvested area increased rapidly from one year to another (541723 fed. in 2013 from the total fruit crops area, which reached about 1609189 fed.) The fruiting acreage of citrus occupies about 439024 fed. and produced about 4098590 tons with an average of 9.336 tons/fed. according to Ministry of Agriculture and Land Reclamation 2013.

Irrigation is one of the most important cultural practices involved in growing citrus in Egypt. The amount of water available under the arid and semiarid regions like Egypt is the main economic limiting factor to the horizontal extension of agriculture and it is almost the only production parameter especially in the newly reclaimed areas. The flood irrigation by gravity and without charging growers any price for the water encourage Egyptian citrus growers to over irrigation for their orchards $\left(7500-800 \mathrm{~m}^{3} / \mathrm{fed} /\right.$ season). This leads to problems of water logging, salinity and leaching of fertility. The irrigation custom creates different problems to both soil and cultivated trees caused by soil water logging, raising soil water table and spreading pathological disorders. The search on citrus irrigation has been reviewed by several authors (Levy et al., 1978 Garicia- Petillo., 1995 and Lai et al., 1997). Fruit set percentage and yield of Washington Navel orang trees increased with irrigation rate $\left(6000 \mathrm{~m}^{3} / \mathrm{fed} /\right.$ year (El-Boray $\boldsymbol{e t}$ al. 1995). Irrigation with percentages from soil moisture depletion considers one of the most important practices to make rationalization for irrigation of Navel orange trees instead of traditional irrigation methods. So, the present research is dealing with determining the optimum water requirement for navel orange through investigating the following two main targets:

1. The effect of studied water regimes on some water relations, yield, yield components and fruit quality.

2. Identify the most suitable percentage of available soil moisture depletion which can irrigate Navel orange trees on it without any drastic effect on yield and fruit quality.

\section{Materials and Methods}

The field investigation were performed during the two successive growing seasons 2013 and 2014 on 40 years old, Washington Navel orange trees "Citrus sinensis L. budded on sour orange rootstock, spaced at $5 \times 5$ meters and grown in private orchard located at 
Desok district, Kafr El-Sheikh Governorate, Egypt. Selected trees were good health and nearly uniform in both vegetative growth and fruit load. Twenty trees were selected in this present study and divided randomly into four groups, where each group was subjected to one of the following irrigation treatments. The experimental design was randomized completely block as follow:

- Control (Traditional irrigation) $\left(\mathrm{I}_{1}\right)$

- Irrigation when $25 \%$ of available soil moisture was depleted $\left(\mathrm{I}_{2}\right)$,
- Irrigation when $50 \%$ of available soil moisture was depleted $\left(\mathrm{I}_{3}\right)$

- $\quad$ Irrigation when $75 \%$ of available soil moisture was depleted $\left(\mathrm{I}_{4}\right)$

Irrigation treatments were started after the trees received the winter irrigation in February

Soil physical, chemical properties, some water constants were determined according to (Klute, 1986 and Jackson 1973) and mean of some meteorological data of the experimental site were shown in Tables $(1,2$ and 3).

Table 1. Some physical analysis of the soil of the experimental site.

\begin{tabular}{|c|c|c|c|c|c|c|c|c|}
\hline \multirow{2}{*}{ Soil depth $(\mathrm{cm})$} & \multicolumn{3}{|c|}{ Particle size distribution, $\%$} & \multirow{2}{*}{$\begin{array}{c}\text { Texture } \\
\text { class }\end{array}$} & \multirow{2}{*}{$\begin{array}{c}\text { Bulk } \\
\text { density } \\
\mathrm{Kg} / \mathrm{m}^{3}\end{array}$} & \multirow{2}{*}{$\begin{array}{c}\text { Field } \\
\text { capacity } \\
\%\end{array}$} & \multirow{2}{*}{$\begin{array}{l}\text { Wilting } \\
\text { point \% }\end{array}$} & \multirow{2}{*}{$\begin{array}{c}\text { Available } \\
\text { water } \%\end{array}$} \\
\hline & Sand & silt & clay & & & & & \\
\hline 0-15 & 16.89 & 23.97 & 59.14 & Clayey & 1.16 & 47.0 & 25.3 & 21.7 \\
\hline $15-30$ & 16.55 & 25.57 & 57.88 & Clayey & 1.24 & 39.0 & 21.8 & 17.2 \\
\hline $30-45$ & 16.22 & 24.52 & 59.26 & Clayey & 1.33 & 38.0 & 21.9 & 16.1 \\
\hline $45-60$ & 17.60 & 26.26 & 56.14 & Clayey & 1.37 & 38.5 & 20.8 & 17.7 \\
\hline mean & 16.57 & 25.08 & 58.11 & Clayey & 1.28 & 40.6 & 22.5 & 18.2 \\
\hline
\end{tabular}

Table 2. Some chemical properties of the soil of the experimental site.

\begin{tabular}{|c|c|c|c|c|c|c|c|c|c|c|}
\hline \multirow{2}{*}{ Soil depth $(\mathrm{cm})$} & \multirow{2}{*}{$\begin{array}{c}\mathrm{EC} \\
\mathrm{dS} / \mathrm{m}\end{array}$} & \multirow{2}{*}{$\mathrm{pH}$} & \multicolumn{4}{|c|}{ Soluble cations, meq/L } & \multicolumn{4}{|c|}{ Soluble anions, meq/l } \\
\hline & & & $\mathrm{Na}^{+}$ & $\mathrm{K}^{+}$ & $\mathrm{C}^{\mathrm{a}++}$ & $\mathrm{Mg}^{++}$ & $\mathrm{CO}_{3}{ }^{--}$ & $\mathrm{HcO}_{3}{ }^{-}$ & $\mathrm{Cl}^{-}$ & $\mathrm{SO}_{4}^{--}$ \\
\hline $0-15$ & $1-50$ & 8.25 & 0.76 & 0.02 & 0.30 & 0.10 & - & 0.55 & 0.21 & 0.42 \\
\hline $15-30$ & 1.57 & 8.22 & 0.79 & 0.02 & 0.31 & 0.10 & -- & 0.57 & 0.22 & 0.43 \\
\hline $30-45$ & 1.65 & 8.26 & 0.89 & 0.02 & 0.34 & 0.10 & -- & 0.65 & 0.23 & 0.47 \\
\hline $45-60$ & 2.78 & 8.29 & 1.25 & 0.03 & 0.84 & 0.27 & -- & 0.45 & 0.23 & 1.71 \\
\hline Mean & 1.88 & 8.26 & 0.92 & 0.02 & 0.45 & 0.14 & -- & 0.56 & 0.22 & 0.76 \\
\hline
\end{tabular}

Table 3. Mean of some meteorological data for Kafr El-Sheikh area during 2013 and 2014 seasons.

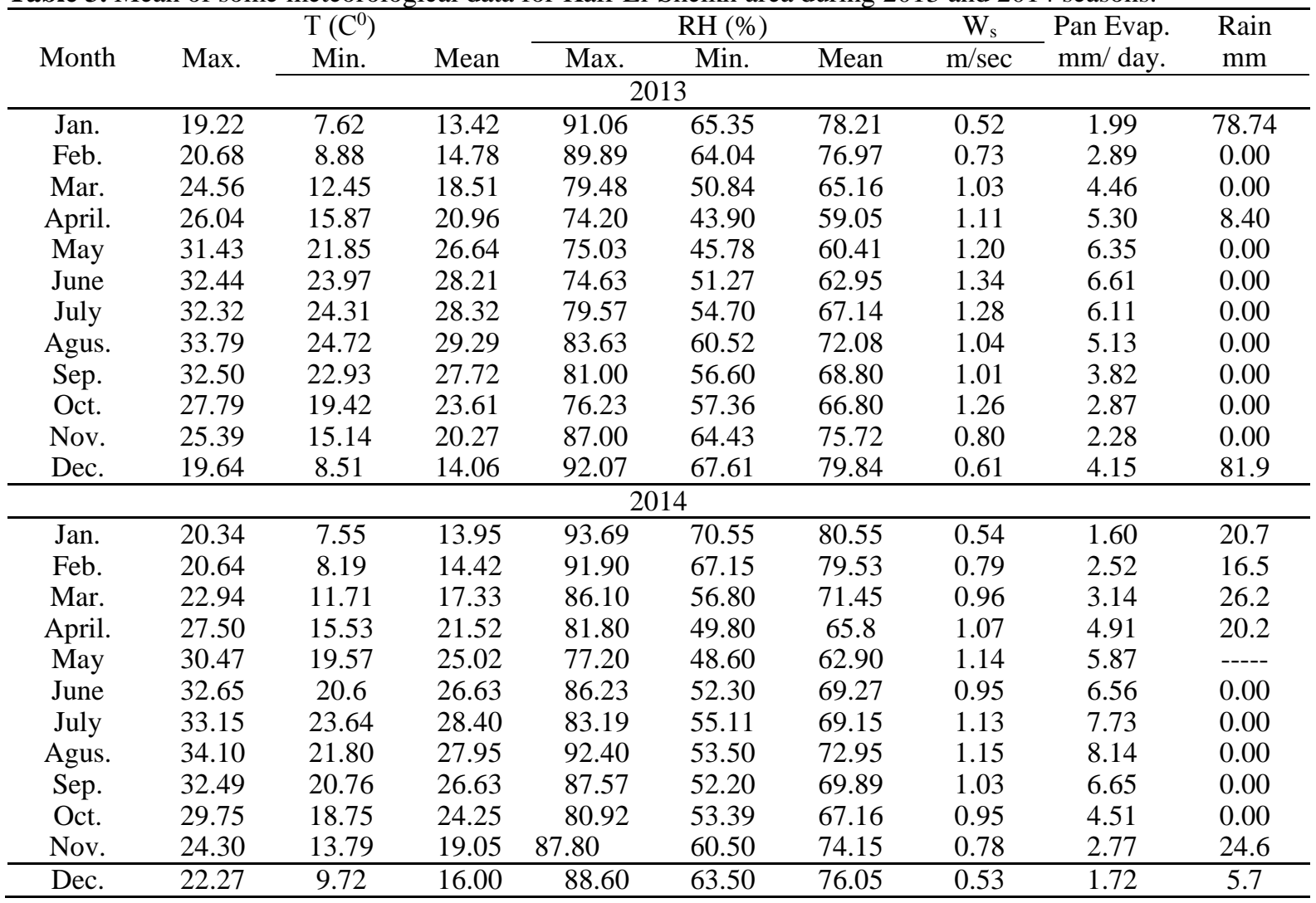




\section{Data collection}

Water relations:

1. Amount of irrigation applied water

Applied water was computed as described by Giriappa(1983)

Where:-

$$
\mathrm{AW}=\mathrm{IW}+\mathrm{Re}
$$

\section{Irrigation water delivered}

Submerged flow orifice with fixed dimension was used to convey and measure the irrigation applied water, as the following equation (Michael, 1978).

$$
\mathrm{Q}=\mathrm{CA} \sqrt{2 \mathrm{gh}}
$$

Where:-

$\mathrm{Q}=$ Discharge thought orifice $\left(\mathrm{cm}^{3} \mathrm{sec}^{-1}\right)$,

$\mathrm{C}=$ Coefficient of discharge (0.61),

$\mathrm{A}=$ Cross sectional area of orifice, $\mathrm{cm}^{2}$,

$\mathrm{g}=$ Acceleration due to gravity, $\mathrm{cm} / \sec ^{2}(980$ $\mathrm{cm} / \mathrm{sec}$ ) and

$\mathrm{h}=$ pressure head, over the orifice center, $\mathrm{cm}$.

\section{Water consumptive use (CU)}

It is the sum of water volumes used by the vegetative growth in building the plant tissue, transpiration plus what evaporated from adjacent soil. Water consumptive use by Navel orange trees was computed gravimetrically as differences in soil moisture content in the soil samples taken before and after irrigation on oven dry basis. Transformation to water consumptive use $\left(\mathrm{m}^{3} / \mathrm{fed}\right)$ was calculated using the following equation (Israelson and Hansen, 1962).

$$
\mathrm{CU}=\sum_{\substack{i=1 \\ i=1}}\left\{\left[\left(\varnothing_{2}-\varnothing_{1}\right) \times \mathrm{Dbi} \times \mathrm{di} \times\right.\right.
$$

Where:

$\mathrm{CU}=$ water consumptive use in $\mathrm{m}^{3} / \mathrm{fed}$.

$\emptyset_{2}=$ soil moisture $\%$ after irrigation in the $i^{\text {th }}$ layer

$\emptyset_{1}=$ soil moisture $\%$ before next irrigation in the $i^{\text {th }}$ layer

Dbi $=$ bulk density in $\mathrm{kg} / \mathrm{m}^{3}$ of the $\mathrm{i}^{\text {th }}$ layer

$\mathrm{di}=$ depth of the $\mathrm{i}^{\text {th }}$ layer, $\mathrm{m}$.

$4200=$ feddan area in $\mathrm{m}^{2}$

$\mathrm{I}=$ No. of soil layers,

$\mathrm{n}=$ No. of irrigations

\section{Water stored in the effective root zone} (WS)

Seasonal water stored (WS) was calculated using the following equation

$$
\mathrm{WS}=\sum_{\substack{i=1 \\ i=1}}\left\{\left[\left(\varnothing_{2}-\varnothing_{1}\right) \times \mathrm{Dbi} \times \mathrm{di} \times\right.\right.
$$

Where:-

$\varnothing_{2}=$ soil moisture $\%$ after irrigation in the $\mathrm{i}^{\text {th }}$ layer

$\varnothing_{1}=$ soil moisture $\%$ before next irrigation in the $\mathrm{i}^{\text {th }}$ layer

(I.e. directly, before and after the same irrigation)

Determination of soil moisture percentage

It was calculated as described by $\operatorname{Garica}(1978)$.

\section{Irrigation application efficiency (Ea)}

It is defined as a ratio between the amount of stored water $\left(\mathrm{m}^{3} / \mathrm{fed}\right)$ and the amount of the applied water $\left(\mathrm{m}^{3} / \mathrm{fed}\right)$ as described by Downy (1970).

Where:-

$$
\mathrm{Ea}=(\mathrm{Ws} / \mathrm{Wa}) \times 100
$$

Ws, Wa are the volumetric water stored and the volumetric water applied, respectively.

5. Consumptive use efficiency (ECU). (\%)

Consumptive use efficiency was computed according to Doorenbos and Pruitt (1975) as follows:

Where:

$$
\mathrm{ECU}=(\mathrm{Cu} / \mathrm{Aw}) \times 100
$$

ECU $=$ Consumptive use efficiency $(\%)$,

$\mathrm{Cu}=$ Consumptive use $\left(\mathrm{m}^{3} / \mathrm{fed}\right)$ and

$\mathrm{AW}=$ applied water $\left(\mathrm{m}^{3} / \mathrm{fed}\right)$

Water productivity $\left(\mathrm{WP}, \mathrm{kg} / \mathrm{m}^{3}\right)$ and productivity of irrigation water (PIW, $\mathrm{kg} / \mathrm{m}^{3}$ )

Water productivity and productivity of irrigation water were calculated according to Ali $\boldsymbol{e t}$ al., (2007) as follows:

Where:

$$
\mathrm{WP}=\mathrm{Y} / \mathrm{Cu} \text { and } \mathrm{PIW}=\mathrm{Y} / \mathrm{AW}
$$

$\mathrm{WP}=$ water productivity $\left(\mathrm{kg} / \mathrm{m}^{3}\right)$,

$\mathrm{Y}=$ marketable yield $(\mathrm{kg} / \mathrm{fed}$.$) ,$

$\mathrm{Cu}=$ water consumptive use $\left(\mathrm{m}^{3} / \mathrm{fed}.\right)$,

PIW =productivity of irrigation water $\left(\mathrm{kg} / \mathrm{m}^{3}\right)$ and

$\mathrm{AW}=$ Seasonal water applied $\left(\mathrm{m}^{3} /\right.$ fed. $)$.

\section{Determination of yield:}

At harvesting time $\left(18^{\text {th }}\right.$ and $23^{\text {rd }}$ December $)$ in the first and second seasons, respectively. Fruit weight ( $\mathrm{g}$ ). fruit number/tree, yield $\mathrm{kg} / \mathrm{tree}$, yield $\mathrm{kg} / \mathrm{fed}$ and yield ton / fed. Were estimated.

\section{Fruit quality}

\section{1- Physical properties of fruits:-}

Ten fruits of Washington navel orange were randomly taken from the yield for each replicate and 
the following determination was carried out :-( Peel firmness $\left(\mathrm{kg} / \mathrm{cm}^{2}\right)$, Peel thickness $(\mathrm{mm})$ and Juice weight percentage)

\section{2- Chemical properties of fruit:-}

The same fruit samples used in studying the fruit physical properties were also used in determination of chemical properties (soluble solid content (SSC), tetra table acidity, SSC: acid ratio, Vitamin) content was determined in juice according to (A.O.A.C., 1990).

\section{Chemical constituents of leaves:}

The samples of leaves were randomly taken for estimating minerals content. In addition, nitrogen: it was determined by using the Micro-Kjeldahl method (Chapman and Pratt 1978).Phosphorus, it was determined by using the spectrophotometers (Murphy and Riely, 1962).Potassium determined according to (Jackson, 1973).

\section{Statistical analysis}

The obtained data were statistically analyzed as randomized complete block design according to (Snedecor and Cochran, 1980) and treatment means were compared using Duncan Multiple Range Test (DMRT) (Duncan, 1955).

\section{Results and Discussions}

Effect of irrigation treatments on:-
1. Amount of applied water $\left(\mathrm{m}^{3} / \mathrm{fed}\right.$.

Data presented in Table (4) cleared that the values of water applied were affected by irrigation treatment $I_{1}, I_{2}, I_{3}$ and $I_{4}$ the both seasons. The highest values (7838.4 and $7389.8 \mathrm{~m}^{3}$ /fed.) were recorded under irrigation treatment $\mathrm{I}_{1}$. While the lowest was obtained by $\mathrm{I}_{4}\left(4628.8\right.$ and $4800.6 \mathrm{~m}^{3}$ /fed.) in the first and second seasons, respectively. Generally, the seasonal values of pplied water can be descended in a descending order i.e. $I_{1}>I_{2}>I_{3}>I_{4}$ in both season. Increasing the seasonal values of applied water under irrigation treatment $\mathrm{I}_{1}$ (traditional irrigation) for Navel orange trees in comparison with other irrigation treatments which exposed to water stress might be attributed to decreasing irrigation intervals and hence increasing number of irrigations. These results are in great harmony with those obtained by Treeby et al., (2007) on Navel orange, El-Abd et al.,., (2012) and Abo El-Enien (2012) showed that the highest values for water applied were recorded under traditional treatment compared with other treatments which irrigated after depleting different percentages from soil field capacity in both seasons.

Table 4. Effect of irrigation treatments on amount of irrigation applied water for Navel orange trees in the North Middle Delta during 2013 and 2014 seasons.

\begin{tabular}{|c|c|c|c|c|c|}
\hline \multirow[t]{2}{*}{$\begin{array}{l}\text { Irrigation } \\
\text { treatments } \\
\text { (I) }\end{array}$} & \multirow{2}{*}{\multicolumn{2}{|c|}{$\begin{array}{c}\text { Amount of applied water at } \\
\text { each irrigation } \\
\left(\mathrm{m}^{3} / \mathrm{fed} .\right)\end{array}$}} & \multicolumn{2}{|c|}{$\begin{array}{l}\text { Seasonal } \mathrm{r} \text { appliedwate } \\
\qquad\left(\mathrm{m}^{3} / \mathrm{fed}\right)\end{array}$} & \multirow[t]{2}{*}{$\begin{array}{l}\text { The over all means values } \\
\text { through the two season }\end{array}$} \\
\hline & & & 2013 & 2014 & \\
\hline $\mathrm{I}_{1}$ & 340.8 & 335.9 & 7838.4 & 7389.8 & 7614.1 \\
\hline $\mathrm{I}_{2}$ & 350.3 & 359.4 & 7006.0 & 6828.6 & 6917.05 \\
\hline $\mathrm{I}_{3}$ & 380.9 & 387.3 & 6475.3 & 6196.8 & 6336.05 \\
\hline $\mathrm{I}_{4}$ & 420.8 & 428.3 & 4628.8 & 4800.6 & 4714.7 \\
\hline
\end{tabular}

2. Seasonal consumptive use $\left(\mathrm{m}^{3} / \mathrm{fed}, \mathrm{cm}\right.$.)

Tabulated data in Table (5) showed that the highest values $\left(4781.4 \mathrm{~m}^{3} / \mathrm{fed},(113.8 \mathrm{~cm})\right.$ and 4581.7 $\left.\mathrm{m}^{3} / \mathrm{fed},(109.1 \mathrm{~cm})\right)$ were recorded under irrigation treatment $\mathrm{I}_{1}$. On the contrary, the lowest values $\left(3008.7 \mathrm{~m}^{3} / \mathrm{fed},(71.6 \mathrm{~cm})\right.$ and $3189.7 \mathrm{~m}^{3} / \mathrm{fed},(75.9$ $\mathrm{cm})$ were obtained by $\mathrm{I}_{4}$ in both seasons, respectively. These results are in a great agreement with those reported by El-Abd et al., (2012) who concluded that the highest values for seasonal amount of consumptive use in two growing seasons were recorded under traditional irrigation (16 irrigations through the whole growing season) in comparison with other irrigation treatments which received (12) and (8) irrigation through the whole growing season.

Table 5. Effect of irrigation treatments on amount of seasonal water consumptive use for Navel orange trees in the North Middle Delta region during 2014 and 2014 seasons.

\begin{tabular}{ccccccc}
\hline \multirow{2}{*}{$\begin{array}{c}\text { Irrigation } \\
\text { treatments } \\
(\mathrm{I})\end{array}$} & \multicolumn{3}{c}{$\begin{array}{c}\text { Seasonal water consumptive use } \\
\left(\mathrm{cm} \text { and } \mathrm{m}^{3} / \mathrm{fed} .\right)\end{array}$} & $\begin{array}{c}\text { The overall mean values } \\
\text { through the two seasons }\end{array}$ \\
\cline { 2 - 7 } & $\mathrm{Cm}$, & 2013 & $\mathrm{Cm}$, & $\mathrm{m}^{3} / \mathrm{fed}$ & $\mathrm{Cm}$, & $\mathrm{m}^{3} / \mathrm{fed}$ \\
\hline $\mathrm{I}_{1}$ & 113.8 & 4781.4 & 109.1 & 4581.7 & 111.5 & 4681.6 \\
$\mathrm{I}_{2}$ & 105.1 & 4413.8 & 102.4 & 4302.0 & 103.8 & 4357.9 \\
$\mathrm{I}_{3}$ & 98.7 & 4144.2 & 97.1 & 4079.4 & 97.9 & 4111.8 \\
\hline $\mathrm{I}_{4}$ & 71.6 & 3008.7 & 75.9 & 3189.7 & 73.8 & 3099.2 \\
\hline
\end{tabular}


Amount of stored water $\left(\mathrm{m}^{3} /\right.$ fed) in the effective root zone and water application efficiency $(\%)$.

Data in Table (6) showed that, the highest overall mean value $\left(5491.6 \mathrm{~m}^{3}\right.$ /fed.) was recorded under irrigation treatment $I_{1}$ (traditional irrigation). In the contrary, the lowest overall mean value $\left(3909.2 \mathrm{~m}^{3}\right.$ /fed) was recorded under irrigation treatment $\mathrm{I}_{4}$ (irrigation when $75 \%$ of available soil moisture was depleted).These results are in a great harmony with those obtained by Beshara (2012) on wheat and EIAbd et al., (2012) on Washington Navel orange

Water application efficiency $(\%)$
Data in table (6) clearly showed that the overall mean values of water application efficiency were affected by irrigation treatments. The highest overall mean value $82.90 \%$ was recorded under irrigation treatment $\mathrm{I}_{4}$ irrigation when $75 \%$ of available soil moisture depletion, comparing with other irrigation treatments $I_{1}, I_{2}$ and $I_{3}(72.15,74.71$ and 77.71), respectively. Increasing the overall mean values of water application under stress conditions comparing with other irrigation treatments might be attributed to decreasing the amount of applied water under the condition of these treatments. These results are in a great harmony with those obtained by El-Abd $\boldsymbol{e t}$ al., (2012) on Washington Navel orange.

Table 6. Effect of irrigation treatments on amount of stored water in the effective root zone $\left(\mathrm{m}^{3} /\right.$ fed.) and water application efficiency (\%) on Navel orange trees during 2013 and 2014 seasons.

\begin{tabular}{ccccccc}
\hline $\begin{array}{c}\text { Irrigation } \\
\text { treatments } \\
(\mathrm{I})\end{array}$ & $\begin{array}{c}\text { Stored water } \\
\left(\mathrm{m}^{3} / \text { fed. }\right)\end{array}$ & $\begin{array}{c}\text { Water application } \\
\text { efficiency } \\
(\%)\end{array}$ & $\begin{array}{c}\text { The overall mean } \\
\text { values for stored } \\
\text { water in both } \\
\text { seasons }\end{array}$ & $\begin{array}{c}\text { The overall mean } \\
\text { values for water } \\
\text { application } \\
\text { efficiency in both } \\
\text { seasons }\end{array}$ \\
\cline { 2 - 5 } & 2013 & 2014 & 2013 & 2014 & & 72.15 \\
$\mathbf{I}_{\mathbf{1}}$ & 5591.4 & 5391.7 & 71.33 & 72.96 & 5491.6 & 74.71 \\
$\mathbf{I}_{\mathbf{2}}$ & 5223.8 & 5112.0 & 74.56 & 74.86 & 5167.9 & 77.71 \\
\hline $\mathbf{I}_{\mathbf{3}}$ & 4954.2 & 4889.4 & 76.51 & 78.90 & 4921.8 & 82.90 \\
\hline
\end{tabular}

Consumptive use efficiency (ECU\%)

Data in Fig (1) showed the effect of irrigation treatments on consumptive use efficiency $\%$. The results revealed that the highest values in these respect obtained by treatment $\mathrm{I}_{4}$ followed by $\mathrm{I}_{3}$ compared with the lowest values obtained by control treatment. Increasing the mean values for consumptive use efficiency under stressed treatments might be attributed to decreasing amount of water applied. These results are in the same line with those obtained by Doorenbos and Kassam (1979), Velez et al., (2007) on citrus, Buendia, et al.,.(2008) on peach trees and El-Abd et al.,. (2012).

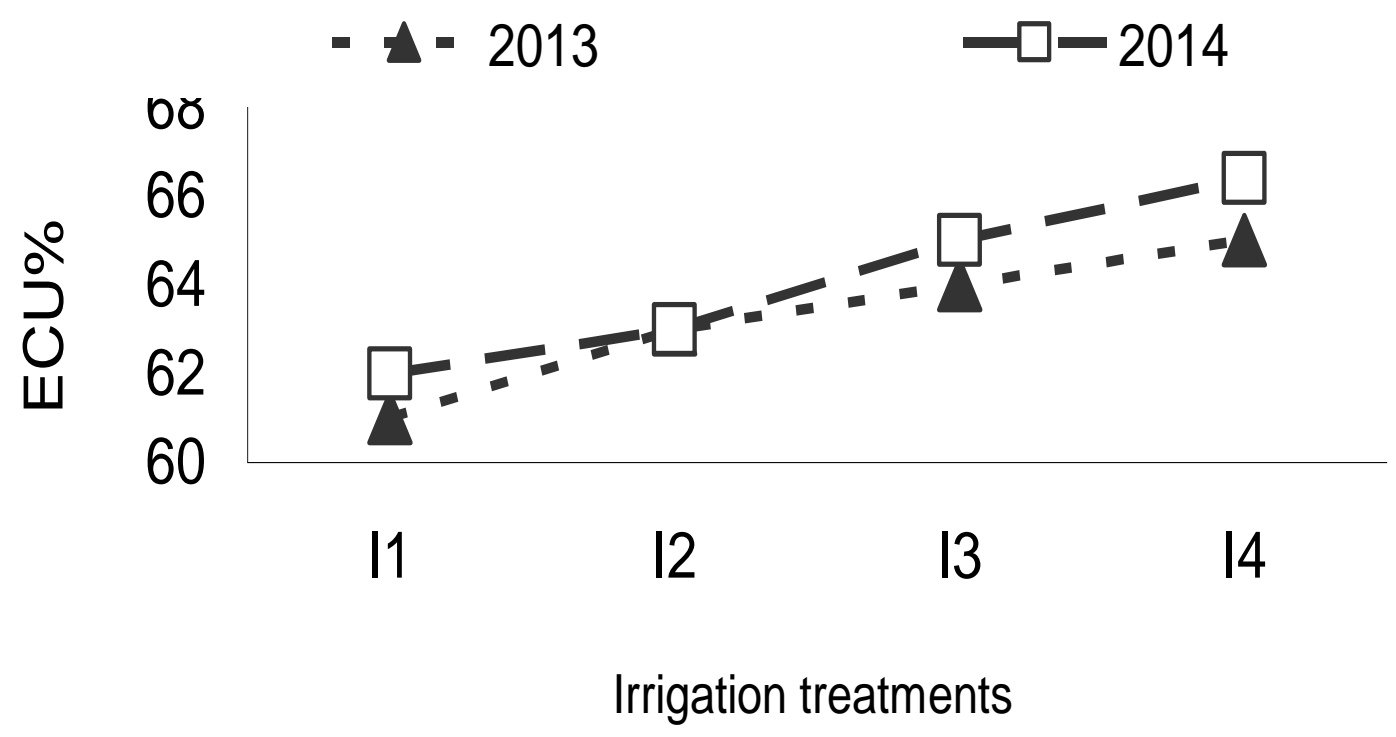

Fig 1: $\quad$ Effect of irrigation treatments on consumptive efficiency (\%) on Navel orange trees in North Middle Nile Delta region during 2013 and 2014 seasons. 
Water productivity (WP, $\mathrm{kg} / \mathrm{m}^{3}$ ) and productivity of irrigation water $\left(\mathrm{PIW}, \mathrm{kg} / \mathrm{m}^{3}\right)$

Data in Fig. (2) showed that the values of water productivity $\left(\mathrm{WP}, \mathrm{kg} / \mathrm{m}^{3}\right.$ ) are higher than those for productivity of irrigation water $\left(\mathrm{PIW}, \mathrm{kg} / \mathrm{m}^{3}\right)$ in both seasons. This might be due to decreasing the values of consumed water comparing with applied water. The highest values were recorded by $\mathrm{I}_{2}, \mathrm{I}_{3}$ and $\mathrm{I}_{4}$ treatments comparing with irrigation treatment $\mathrm{I}_{1}$ (traditional irrigation method) especially treatment $\mathrm{I}_{3}$ (irrigation when $50 \%$ of available soil moisture was depleted) for the two studied efficiencies in the two growing seasons and the values were 7.51 and 7.52 $\mathrm{kg} / \mathrm{m}^{3}$ for water productivity and 4.81 and $4.95 \mathrm{~kg} / \mathrm{m}^{3}$ for productivity of irrigation water in the first and second growing seasons respectively. Increasing the mean values of water productivity and productivity of irrigation water under stress conditions comparing with non-stressed ones might be due to decreasing amount of consumed water and applied water. Consequently, increasing the mean values of water productivity and productivity of irrigation water in the two growing seasons. These results are in a great harmony with those obtained by El-Abd $\boldsymbol{e t}$ al, (2012) on Washington Navel orange.

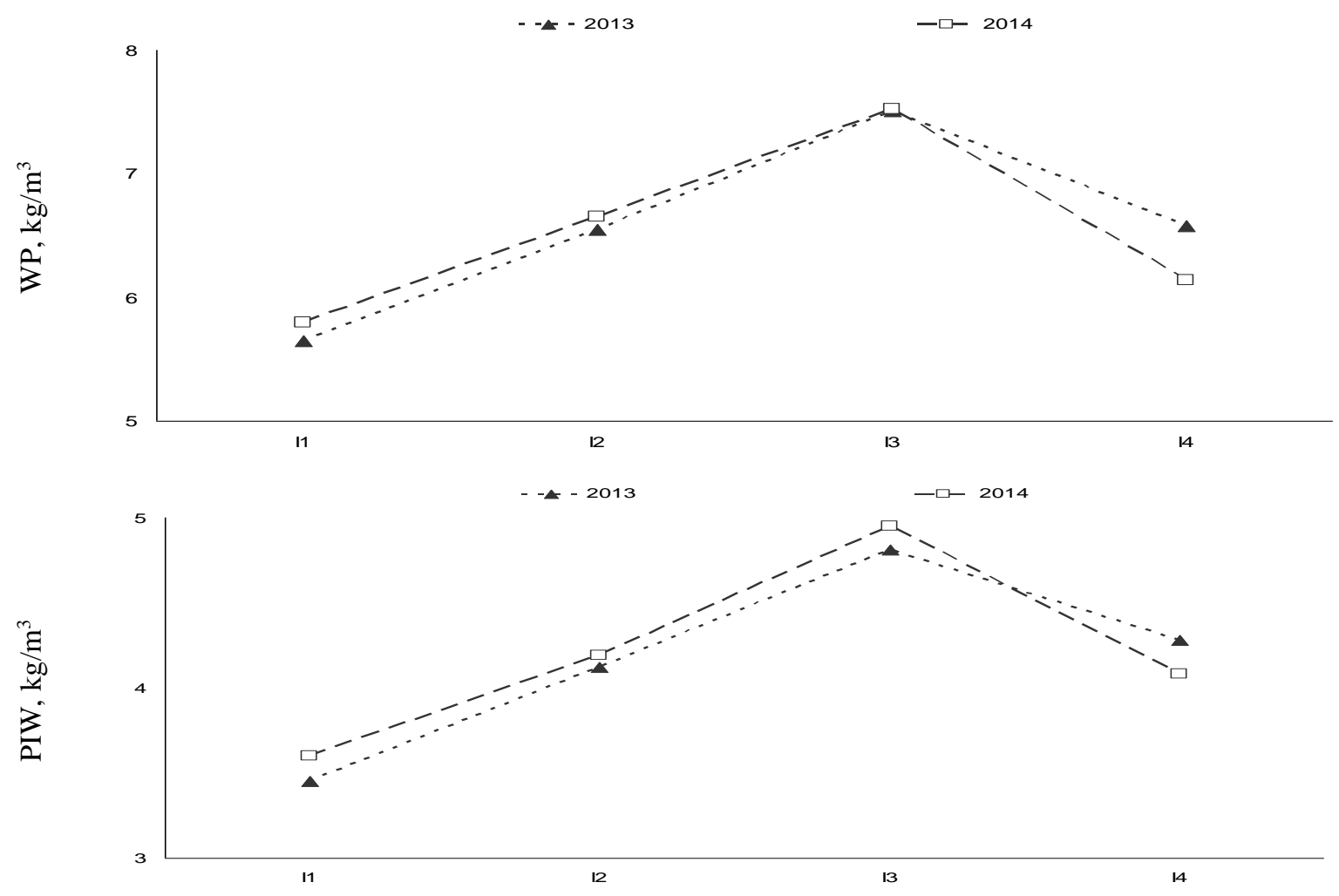

Irrigation treatments

Fig (2): Effect of irrigation treatments on water productivity (WP, $\mathrm{kg} / \mathrm{m}^{3}$ ) and productivity of irrigation water (PIW, $\mathrm{kg} / \mathrm{m}^{3}$ ) on Navel orange trees in the North Middle Nile Delta region during 2013 and 2014 seasons.

\section{Effect of irrigation treatments on yield and fruit quality of Navel orange.}

Yield expressed as number of fruits/tree and weight of harvested fruits ( $\mathrm{kg} /$ tree or ton/fed.)

\section{1- Yield as number of harvested fruits /tree} Regarding fruit number/tree data in the Table(7) showed the highest fruit number 665.7 and 659.0/tree were recorded under irrigation treatment $\mathrm{I}_{3}$ (irrigation when $50 \%$ available soil moisture was depleted). On the other hand, the lowest values (454.3 and $450.3 /$ tree) were recorded under irrigation treatment $\mathrm{I}_{4}$ (irrigation when $75 \%$ available soil moisture was depleted) in the first and second growing seasons, respectively. Decreasing number of fruit /tree under irrigation treatments $I_{4}$ and $I_{1}$ might be attributed to increasing number of fruit drop under the conditions of theses treatments (strict water stress, $\mathrm{I}_{4}$ and excessive irrigation, $I_{1}$ ) but increasing fruit number/tree under the conditions of irrigation treatment $\mathrm{I}_{3}$ (irrigation when $50 \%$ available soil moisture was depleted) because this consider the best suitable level from available water depletion to irrigate Navel orange trees on it to avoid excess and stress condition to give the highest number of fruit set and decreasing fruit drop. These results are in a great harmony with those obtained by El-Abd (2005), El-Abd et. Al. (2012) and Abo El-Enein (2012) on Navel orange trees. 


\section{Yield as $\mathrm{kg}$ of harvested fruits/tree and} ton/fed.

Data in Table (7) declared that, the fruit yield $\mathrm{kg} / \mathrm{tree}$ and ton/fed. Were highly significant affected by irrigation treatments. The highest values were recorded by irrigation treatment $\mathrm{I}_{3}$ (irrigation when $50 \%$ available soil moisture was depleted) comparing with other irrigation treatments $\mathrm{I}_{1}, \mathrm{I}_{2}$ and $\mathrm{I}_{4}$ which exposed to excessive water applied $\left(\mathrm{I}_{1}\right.$ an $\left.\mathrm{I}_{2}\right)$ and that exposed to strict water stress $\left(\mathrm{I}_{4}\right)$. But the lowest one recorded under irrigation treatment $\mathrm{I}_{4}$ in both seasons. Increasing the fruit yield under irrigation treatment $\mathrm{I}_{3}$ in comparison with other irrigation treatments $\mathrm{I}_{1}, \mathrm{I}_{2}$ and $\mathrm{I}_{4}$ might be due to increasing number of fruits/tree under the conditions of this treatment. These results are in a great harmony with those obtained by El-Boray et al. (1995), El-Abd (2005), Garica-Tejero et al., (2010), El-Abd et al., (2012) and Abo El- Enien (2012) on Washington Navel orange trees.

Table 7. Effect of irrigation treatments on yield of Navel orange trees in North Delta region during 2013 and 2014 seasons.

\begin{tabular}{ccccccc}
\hline \multirow{2}{*}{$\begin{array}{c}\text { Irrigation } \\
\text { treatments }\end{array}$} & \multicolumn{2}{c}{ Fruit number/tree } & \multicolumn{2}{c}{ Yield kg/tree } & \multicolumn{2}{c}{ Yield ton/fed. } \\
\cline { 2 - 7 }$(\mathrm{I})$ & 2013 & 2014 & 2013 & 2014 & 2013 & 2014 \\
\hline $\mathrm{I} 1$ & $531.7 \mathrm{c}$ & $532.3 \mathrm{c}$ & $168.9 \mathrm{c}$ & $166.3 \mathrm{c}$ & $27.02 \mathrm{c}$ & $26.61 \mathrm{c}$ \\
$\mathrm{I} 2$ & $581.6 \mathrm{~b}$ & $582.70 \mathrm{~b}$ & $180.6 \mathrm{~b}$ & $178.9 \mathrm{~b}$ & $28.89 \mathrm{~b}$ & $28.62 \mathrm{~b}$ \\
$\mathrm{I} 3$ & $665.6 \mathrm{a}$ & $659.0 \mathrm{a}$ & $194.6 \mathrm{a}$ & $191.8 \mathrm{a}$ & $31.25 \mathrm{a}$ & $30.69 \mathrm{a}$ \\
$\mathrm{I} 4$ & $454.3 \mathrm{~d}$ & $450.3 \mathrm{~d}$ & $123.7 \mathrm{~d}$ & $122.4 \mathrm{~d}$ & $19.79 \mathrm{~d}^{*}$ & $19.58 \mathrm{~d}$ \\
\hline F test & $* *$ & $* *$ & $* *$ & $* *$ & $* *$ & $* *$ \\
\hline
\end{tabular}

\section{Fruit quality}

2.1. Physical properties:

1- $\quad$ Fruit weight:

Data presented in Table (8) revealed that, the mean values of fruit weight $(\mathrm{g})$ were highly significant affected by irrigation treatments in both seasons. The highest values were recorded under irrigation treatment $\mathrm{I}_{1}$ (control), but the lowest values were recorded under irrigation treatment $\mathrm{I}_{4}$ (irrigation when $75 \%$ available soil moisture was depleted) during both seasons. These results are in a great harmony with those obtained by El-Boray et al., (1995), Abd El-Aziz, (1998), El-Abd (2005) and Abo El-Enein (2012) on Navel orange trees. They mentioned that fruit weights were markedly increased by irrigation increase.

2-Peel firmness, peel thickness and Juice percentage:
Data presented in Table (8) indicated that, there were statistical differences among all treatments. The highest values of peel firmness and thickness recorded with irrigation treatment $\mathrm{I}_{3}$ and $\mathrm{I}_{4}$ without significant differences between them. Both control and irrigation treatment $\mathrm{I}_{2}$ had significantly low values in both seasons. Regarding Juice percentage the highest values were recorded under irrigation treatment $I_{2}$ but the lowest one were recorded under irrigation treatment $\mathrm{I}_{4}$. The reduction in juice percentage under deficit irrigation treatment $\mathrm{I}_{4}$ ((irrigation when $75 \%$ of available soil moisture was depleted) might be attributed to decreasing fruit size and cell water content. These finding were supported by those of Abd-El-Mtaal (1990), El-Abd et al., (2012) and Abo El-Enein (2012) on Navel orange they showed that, moderate water stress produced the highest juice percentage.

Table 8. Effect of irrigation treatments on some fruit physical properties on Navel orange fruits in North Delta region during 2013 and 2014 seasons

\begin{tabular}{ccccccccc}
\hline $\begin{array}{c}\text { Irrigation } \\
\text { treatments }\end{array}$ & \multicolumn{2}{c}{$\begin{array}{c}\text { Average fruit } \\
\text { weight }(\mathrm{g})\end{array}$} & \multicolumn{2}{c}{$\begin{array}{c}\text { Peel firmness } \\
\mathrm{kg} / \mathrm{cm} 2\end{array}$} & \multicolumn{2}{c}{$\begin{array}{c}\text { peel thickness } \\
(\mathrm{mm})\end{array}$} & \multicolumn{2}{c}{$\begin{array}{c}\text { juice percentage } \\
(\%)\end{array}$} \\
\cline { 2 - 9 }$(\mathrm{I})$ & 2013 & 2013 & 2013 & 2014 & 2013 & 2014 & 2013 & 2014 \\
\hline $\mathrm{I} 1$ & $317.6 \mathrm{a}$ & $317.6 \mathrm{a}$ & $8.10 \mathrm{~b}$ & $9.33 \mathrm{~b}$ & $3.67 \mathrm{~b}$ & $3.30 \mathrm{~b}$ & $36.93 \mathrm{~b}$ & $38.93 \mathrm{~b}$ \\
$\mathrm{I} 2$ & $310.4 \mathrm{~b}$ & $310.4 \mathrm{~b}$ & $8.60 \mathrm{~b}$ & $10.10 \mathrm{~b}$ & $3.53 \mathrm{~b}$ & $3.70 \mathrm{~b}$ & $41.17 \mathrm{a}$ & $42.13 \mathrm{a}$ \\
$\mathrm{I} 3$ & $292.3 \mathrm{c}$ & $292.3 \mathrm{c}$ & $11.23 \mathrm{a}$ & $12.03 \mathrm{a}$ & $5.00 \mathrm{a}$ & $4.93 \mathrm{a}$ & $40.43 \mathrm{a}$ & $40.77 \mathrm{a}$ \\
\hline $\mathrm{I} 4$ & $272.3 \mathrm{~d}$ & $272.3 \mathrm{~d}$ & $11.10 \mathrm{a}$ & $12.00 \mathrm{a}$ & $4.90 \mathrm{a}$ & $4.77 \mathrm{a}$ & $34.43 \mathrm{c}$ & $35.47 \mathrm{c}$ \\
F test & $* *$ & $* *$ & $* *$ & $* *$ & $* *$ & $* *$ & $* *$ & $* *$ \\
\hline
\end{tabular}

\section{2-2 Chemical properties}

Data in Table (9) showed the effect of irrigation treatments as compared to control on some fruit chemical properties. Data in both seasons indicated that there were non-significant differences in SSC\%,
SSC/acid and vit $\mathrm{C}$ and acidity in the second season only but in the first one the differences were significantly the trees irrigation with $\mathrm{I}_{4}$ produced fruits with higher acidity. 
Table 9. Effect of irrigation treatments on some fruit chemical properties on Navel orange fruits in North Delta region during 2013 and 2014 seasons.

\begin{tabular}{ccccccccc}
\hline \multirow{2}{*}{$\begin{array}{c}\text { Irrigation } \\
\text { treatment(I) }\end{array}$} & \multicolumn{2}{c}{$\begin{array}{c}\text { SSC } \\
(\%)\end{array}$} & \multicolumn{2}{c}{$\begin{array}{c}\text { Acidity } \\
(\%)\end{array}$} & \multicolumn{2}{c}{ SSC/ Acid ratio } & \multicolumn{2}{c}{$\begin{array}{c}\text { Vit C } \\
(\mathrm{mg} / 100 \mathrm{ml} \text { juice })\end{array}$} \\
\cline { 2 - 9 } & 2013 & 2013 & 2013 & 2014 & 2013 & 2014 & 2013 & 2014 \\
\cline { 2 - 10 } I1 & 11.90 & 11.90 & $0.88 \mathrm{~b}$ & 0.94 & 13.40 & 12.70 & 40.30 & 41.50 \\
$\mathrm{I} 2$ & 12.00 & 12.60 & $0.98 \mathrm{a}$ & 0.97 & 12.30 & 12.90 & 40.60 & 41.90 \\
$\mathrm{I} 3$ & 12.60 & 12.90 & $1.00 \mathrm{a}$ & 102 & 12.50 & 12.80 & 40.70 & 42.40 \\
$\mathrm{I} 4$ & 12.80 & 13.10 & $12.00 \mathrm{a}$ & 1.00 & 12.80 & 13.10 & 40.70 & 42.00 \\
\hline F test & $\mathrm{NS}$ & $\mathrm{NS}$ & $*$ & $\mathrm{NS}$ & $\mathrm{NS}$ & $\mathrm{NS}$ & $\mathrm{NS}$ & $\mathrm{NS}$ \\
\hline
\end{tabular}

Leaf mineral content ( $N, P$ and $K \%)$

Data in table (10) showed the effect of irrigation treatments on leaf mineral content N, P and K of Novel orange trees. There were non-significant differences among treatment on $\mathrm{N}, \mathrm{K}$ leaf content in both seasons. But the differences were significantly in both seasons as for $\mathrm{P}$ content. The control treatment tended to increase $\mathrm{P}$ content followed by $\mathrm{I}_{2}$ and $\mathrm{I}_{3}$ compared to the lowest values obtained $\mathrm{I}_{4}$. These finding are in a great harmony with those obtained by Ismail (2007) and Abo El-Enein(2012) on Washigton Navel orange.

Table 10. Effect of irrigation treatments on leaf mineral contents of Navel orange trees in North Delta region during 2013 and 2014 seasons.

\begin{tabular}{cccccccc}
\hline \multirow{2}{*}{$\begin{array}{c}\text { Irrigation treatments } \\
(\mathrm{I})\end{array}$} & \multicolumn{2}{c}{$\begin{array}{c}\mathrm{N} \\
(\%)\end{array}$} & & $\begin{array}{c}\mathrm{P} \\
(\%)\end{array}$ & & $\mathrm{K}$ \\
& 2013 & 2014 & 2013 & 2014 & 2013 & 2014 \\
\cline { 2 - 8 } & 2.20 & 2.13 & $0.25 \mathrm{a}$ & $0.25 \mathrm{a}$ & 2.63 & 2.83 \\
$\mathrm{I}_{1}$ & 2.23 & 2.17 & $0.22 \mathrm{ab}$ & $0.20 \mathrm{~b}$ & 2.47 & 2.47 \\
$\mathrm{I}_{2}$ & 2.47 & 2.20 & $0.21 \mathrm{ab}$ & $0.20 \mathrm{~b}$ & 2.47 & 2.47 \\
$\mathrm{I}_{3}$ & 2.13 & 2.07 & $0.19 \mathrm{~b}$ & $0.18 \mathrm{~b}$ & 2.27 & 2.40 \\
$\mathrm{I}_{4}$ & $\mathrm{NS}$ & $\mathrm{NS}$ & $*$ & $*$ & $\mathrm{NS}$ & $\mathrm{NS}$ \\
\hline $\mathrm{F}$ test & & & & & & & \\
\hline
\end{tabular}

\section{Conclusion}

In order to face the water stress conditions from which Egypt suffer greatly because of the limitation of water resources from one hand and providing both local and exportable markets with one of the most important orange cultivate that meeting the consumer food diet particularly Egyptian from the other. So, this study recommend that, Navel orange trees in the North Middle Nile Delta region should be irrigated when $50 \%$ of available soil moisture was depleted to obtain the highest yield and maximizing both water productivity and productivity of irrigation water.

\section{References}

Abd El-Aziz,R.A.(1998). Effect of some drip irrigatioin treatments on growth, yield and fruit quality in Valencia orange trees under conditions of newly reclamied land. M.Sc Thesis, Fac. Agric., Zagzig Univ., Egypt.

Abd El-Metaal, M.M. (1990). Effect of some irrigation schedules on growth, yield, fruit quality, water potential and contents of photosynthesis pigments of leaves in citrus.Ph.D Thesis Fac. Agic., Tanta Univ., Egypt

Abo El-Enein, M.M.S. (2012). Improvement of Washington Navel orange fruit quality using water regimes, GA3, potassium and calcium foliar applications. Ph.D. Thesis, Fac. Agric.; Kafr El-Sheikh Univ., Egypt.

Ali, M.H.; M.R. Hoque; A.A. Hassan and A.Khair (2007). Effect of deficit irrigation on yield, water productivity and economic returns of wheat. Agricultural water management 92 (3): 151-161.

Annual Reports of Statistical Institute and Agricultural Economic Research in Egypt (2013).

A.O.A.C. (1990) Association of official analytical chemists, official Methods of Analysis.15th Ed. Washengton D.C., USA.

Beshara,A.T(2012). Effect of soil moisture depletion and nitrogen fertilization application date on Wheat yields, water and fertilizer use efficiencies in north Africa.PhD Thesis. In African studies, Natural Soil Resources. Cairo, Univ.(2012).

Buendia,B.; A.Allenda.; E. Nicolas.; J.j. Alarcon.; I.Gil,M. (2008). Effect of regulated deficit irrigation and crop load on the Antioxidant compounds of peaches. Journal of Agriculture and food chemistry, vol.56, (10) 3601-3608.

Chapman, H.D. and P.F. Pratt (1978). Methods of analysis for soils, plant and water. Univ. California USA.

Downy, L. A. (1970) Water use by maize at three plant densities paper 33, FAO, Rome.

Duncan, D.B. (1955). Multiple ranges and multiple F-tests. Biometrics, 11: 1-42 
Doorenbos J and W.O Pruitt (1975). Guidelines for predicting crop water requirement. FAO. Irrg. Drain.PAP. Rome, P. 24.

Doorenbos, J. and A. Kassam, (1779). Yield response to water: FAO irrigation and drainage paper 33. Rome, Italy: Food and Agriculture organization of United Nations.

El-Abd, A. A.; E.A.Moursi and M.A.Gabr (2012).Effect of irrigation water regime on Navel orange yield, fruit qaulity and some water relation in North Middle Nile Delta region.J. Plant production, Monsoura Univ. 3(6): 1049-1061.

El-Abd, A.A. (2005). Influnce of fertilization and irrigation on Washington Navel orange Orchards, Ph.D Thesis,Fac. Agric. Tanta Univ., Egypt.

El-Boray, M.S.; F.G.Gurguis; M.A.Traqi and A.EL.Hussani (1995). Effect of irrigation and nitrogen fertilization on vegetative growth, yield and fruit quality of Washington Navel orange trees.2. Fruit dropping yield and fruit quality J. Agric.Sci-Mansoura Univ., 20(6):3085-3085.

Garcia, G. (1978). Soil water engineering laboratory manual Colorado State Univ. Dept. of Agric. And chemical Engineering, Fort callins, Colorado, 80523.

Garicia-petillo, M. (1995) Effect of irrigation periods on citrus yield and fruit quality in Uruguay. Microirrigation for achanging world: Cosruing resources/ preserving the Environement. Proceedings of the fifth international Micrirrigation congress, Hyatt Regncy Orlando, Florida, USA.2-6 April, 462-496.

Garica-Terjo,I;A.Jimenez-Bocanegra;M.R.Duran and Z.V.H.Fernandez(2010). Positive impact of regulated deficit irrigation on yield and fruit quality in acommercial citrus orchared (Citrus sinensis L.) cv.Salustiano.Agricultural water Management, 97(5):614-622.
Giriappas, S (1983).Water use efficiency in agriculture.Oxford.IBH publishing $\mathrm{Co}$, New Delhi, 6-9.

Ismail, M.N.H. (2007). Physiological studies on creasing of sweet orange. Ph.D. Thesis, Fac. Agric. Benha Univ.

Israelson, O.W. and V.E. Hansen (1962). Irrigation principles and practice 3rd edition, John Willey $\&$ sons Inc., New York.

Jackson, M.L. (1973). Soil Chemical Analysis prenticle. Hall of India private LTD, New Delhi

Klute,A.(1986). Water retention:Labrotary Method. In: A. Koute (ed.), Methods of soil analysis, part 1.2nd ed. Agron. Monogr. g, ASA, Madison, WI, USA. pp. 635-660.

Lai, H.; Y.K.Hrora; S.P. Bhardwai and P.1. Saroj (1997). Effect of irrigation and spacing on growth, yield and quality behavior of sweet orange on degraded land. Indian Journal of soil Conservation, 25 (3): 222-227.

Levy, Y.; H.Bielorai and J. shalhevet (1978). Longterm effect of different irrigation regimes on grapefruit tree development and yield. J. Amer. Soc. Hort.Sci; 103(3) : 680-683.

Murphy, J. and J.D. Riely (1962). A modified single solution method for determination of phosphate in natural water. Anal. Chem. Acta, 27 : 31-36.

Snedecor, G.W. and W.G. Cochran (1980). Statistical methods, Oxford and J.B.H pup co. Publishing 6th edition. Press Ames Iowa. U.S.A, PP.593

Treeby, M.T.; R.E. Henriod.; K.B.Bevington,; D.J. Milne and R.Storey (2007). Irrigation management and root stock effects on Navel orange (Citrus sinensis ) Fruit quality. Agriculture water Mangement, 91, 1-3 (Jul 16) 24-32.

Velez, J. E.; D.S. Intrigliolo,; J.R.Castel.(2007). Scheduling deficit irrigation of citrus trees with maximum daily trunk shrinkage. Agriculture Water Mangments,90(3):197-204. 


\title{
دراسة سلوك اشجار البرتقال أبوسرة تحت معاملات مختلفة من الرى فى شمال وسط دلتا النيل.
}

\author{
السيد ابو الفتوح مرسى(1) محمد محمد سعد أبو الغنين(2) \\ معهد بحوث الأراضى والمياه والبئية-مركز الحوث الزراعية-الجيزة- مصر

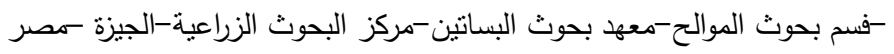

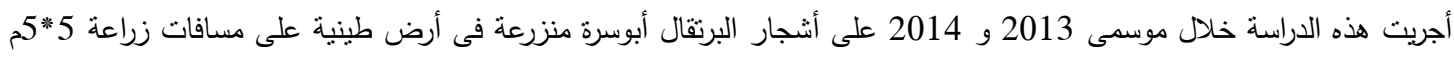

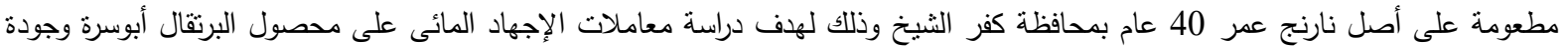

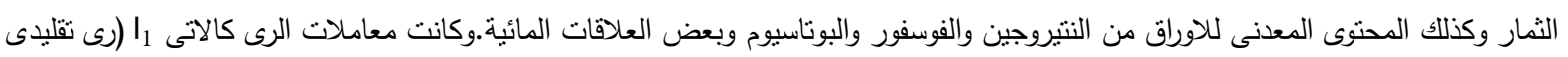

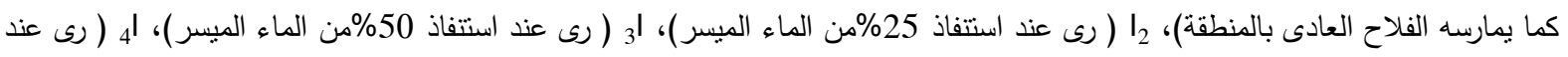

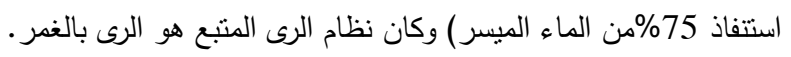

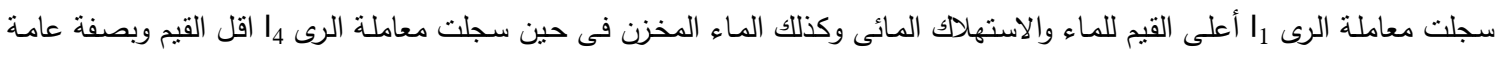

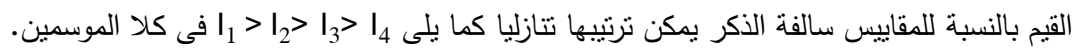

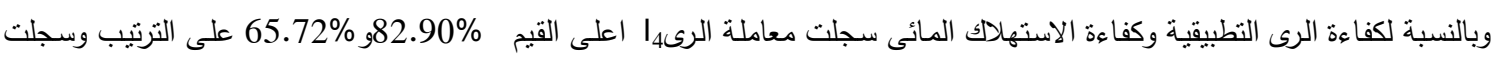

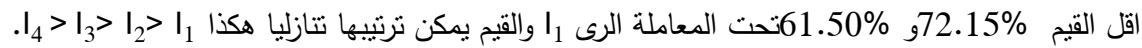

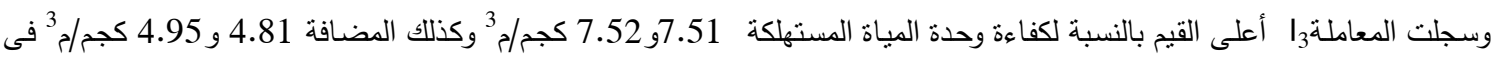
حين سجلت معاملة الرى1ا اقل القيم فى كلا موسمى الدراسة. الأثجار التى تم ريها عند استنفاذ 50\%من الماء الميسر (13) أعطت أعلى القيم فى عدد الثمار/شجرة ، و محصول/فدان فى كلا موسمى الدراسة.

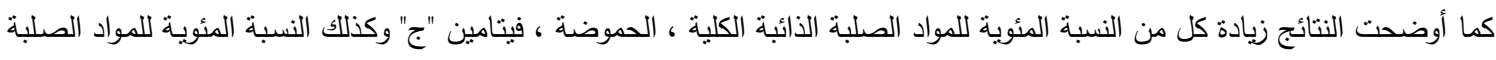

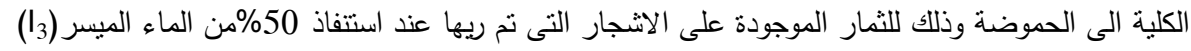

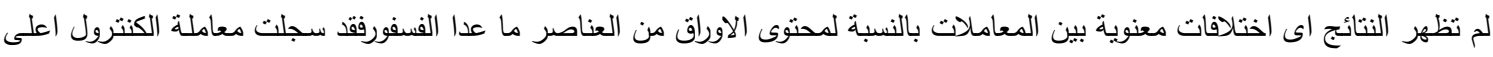
محتوى للاوراق من الفسفور مقارنة بباقى المعاملات. 